\title{
PRODUCTIVE ECONOMIC THINKING - THE BASIS OF FORMATION OF PROFESSIONAL COMPETENCES OF STUDENTS OF THE SPECIALTY "PROFESSIONAL EDUCATION (ECONOMICS)"
}

\author{
Olena Bulavina, \\ $\mathrm{PhD}$ in Economics, Associate Professor Associate Professor of the Department of Pedagogy and Psychology state higher \\ educational institution "Kyiv National Economic University named after Vadym Hetman" \\ https://orcid.org/0000-0002-0198-1838 \\ e-mail: bulavina29@i.ua
}

\begin{abstract}
The paper is devoted to the methodical aspects of the development of economic thinking of future teachers of vocational education and specialists in economics, because its productivity ensures the success of the formation of professional competences of students who receive education by the educational-professional program "Professional Education (Economics)" at state higher educational institution-Kyiv National Economic University named after Vadym Hetman. Competency approach is the trend of modern educational space, and the process of thinking of the person is the center of the problem of personality development and formation of personal and professional competences, which, in turn, (due to uniqueness, originality and synergy) will ensure the competitive advantages of the future specialist in the labor market. The aim of the paper is to analyze the specifics of the economic thinking of students, receiving higher economic education by the program "Professional education (economics)"; formulate the main characteristics (features) of economic thinking that need to be developed in the process of economic education; prove the necessity and substantiate the methodological approaches to the development of productive economic thinking of students, which provides the formation of professional competences in order to stimulate the effectiveness of the professional activity. A wide range of research methods was used to carry out a successful scientific research, namely: analysis and synthesis, scientific substantiation, systematization and generalization, surveys, questionnaires and statistical processing of the results.

During the study, the following conclusions and results were received. The author reveals the specifics of economic thinking, its main features and manifestations in professional activity. Economic thinking is seen as a kind of practical thinking of the subjects of professional activity. This is, first and foremost, a process, and, consequently, it can be developed and improved. Researchers of the nature of the neurons (neurophysiologists) stated the fact that the possibilities of the human brain are limitless. In this perspective, it is necessary to solve the tasks of the methodical nature: how, with the help of which tools economic thinking can be developed as a whole, and in the process of economic training to form its specific characteristics: analyticity, criticism, consistency, constructiveness, predictability, balance, business efficiency, creativity and innovation. Studying these aspects, the author substantiates and systematizes the experience of applying the techniques and technologies of the development of personality thinking in the educational process (based on the example of the academic discipline "Methodology of teaching economic disciplines" and "Training of the development of economic thinking", which have an intersubjective character), taking into account the primary modality of students' thinking; the technologies and techniques for stimulating the development of the logical (left-sided), creative (right-sided) and balanced thinking in the learning process are highlighted separately; their influence on the modality and changes in the types of students' thinking, (which proves the necessity of implementation of specific methods of development of economic thinking in the process of preparation of specialists of the bachelor level on the specialization "Economic and Business Education" in order to stimulate productivity and effectiveness of thinking) is estimated. Under the productivity of economic thinking we understand the number of ideas and solutions developed by the personality due to the subject or scope of the study. The result of the
\end{abstract}


productive economic thinking will be alternatives in solving tasks/problems. And under the effectiveness of economic thinking, we understand the share of ideas and solutions that brought material or immaterial benefits to the personality. The result of the efficient economic thinking is a balanced decision, the adoption of which the received benefit will get over the efforts and resources which were spent on its development and implementation in practice. Horizontal or lateral (creative) thinking will contribute to the productivity of thinking, and vertical or logical thinking - to efficiency. Radiant (associative) thinking will examine decisions thoroughly, tat as a result, will enable you to develop a professional intelligence and on its basis-to create competence of the teacher of vocational training / specialist in economics.

Keywords: economic thinking, productive economic thinking, modality of thinking, professional competence, techniques and methods of thinking development.

Introduction. The system of education of independent Ukraine is in a state of constant reforms. Specialists-educators, scientists and officials, each with his own hand, are trying to build a functioning educational space for the preparation of a competitive expert and a citizen with an active social position. Modern transformations of the educational sector are focused on the issue of forming and the development of professional competence. This also concerns the system of economic education. It is interesting that, in $2015,0.2 \%$ of the world population owned almost a quarter $(21.4 \%)$ of global financial wealth and $20 \%$ of today's millionaires have no higher economic education (according to Forbes Ukraine's data). In 2017 - the number of billionaires increased by 233 persons, and their total assets grew by 1.19 trillion. dollars and amounted to 7.67 trillion dollars. The first 5 billionaires included Microsoft, Berkshire Hathaway, Amazon, Facebook, Bloomberg (Forbes, 2018).

According to the annual report of the World Wealth Report, Consulting Agency Capgemini determined the top three sectors in which by 2025 the largest number of millionaires will work: finance, technology and healthcare. Education took the 7th place (as wealth grows, more people seek to get an education that enables to increase wealth) (Forbes, 2018). Thus, economic specialties will continue to be in public demand.

So, at the moment of the high competitiveness of the labour market, society requires the possession of sufficiently large number of both professional and personal skills from the future specialists. It is not enough to have a high level of knowledge, abilities and skills of professional disciplines, foreign language skills or computer literacy and even a certain experience of the work. Employers pay more attention to the personal characteristics of the candidates, leadership, charisma, communication, responsibility, and especially on creativity and innovation of thinking. And the higher education system, in particular, economic education, has to respond to these challenges adequately.
Materials. The problem of development of economic thinking is interdisciplinary. That's why the author (in his academic searches) concentrates on the research result of domestic and foreign psychologists, educators and economists - representatives of various scientific schools and directions. Very valuable achievements in personal thinking are made by representatives of cognitive psychology (M. Eysenck, U. Niaser et al.), Gestalt psychology (M. Wertheimer, V. Keller, B. Zeigarnik), psychology of activity (L. Vygotsky, O. Leontiev, S. Rubinstein, P. Halperin et al.), neuropsychology (P. Sperry, Michael D. Politis, Richard D. Pelegrino), didactics (Yu. Babansky, V. Bezpalko, B. Matyunin, etc.), economics (A. Maslow, D. Kaneman, R. Thaler). The conclusions and concrete recommendations for the development of certain types and characteristics of thinking by E. de Bono and B. Byuzen have made a significant influence on our searches. Even in 2000, D. Halpern (2000, p. 19) noted that "we are depriving those learners who study the more important component of education - we do not educate the ability to think in them ... Such forms of the study that facilitate the productive thinking are particularly necessary".

But the majority of researches concerns the process of thinking or intelligence of the person, excluding features of his professional activity (eg. field of economics), which identified a range of issues which we try to answer. This work began under the guidance, and then in cooperation with the Candidate of Economic Sciences, Assistant Professor of Pedagogy and Psychology Department O. Aksenova by the support of Doctor of Pedagogy, Professor, Head of Education and Psychology Department of state higher educational institution Kyiv National Economic University named after Vadym Hetman, V. Kozakov even in 2000 and continues to this day.

The purpose of the paper is: to analyze the specifics of the economic thinking of students who receive higher education by the program "Professional Education (Economics)"; formulate the main characteristics (features) of economic thinking that 
need to be developed in the process of economic education; prove the necessity and substantiate the methodological approaches to the development of productive economic thinking of students, which provides formation of professional competences in order to stimulate the effectiveness of the professional activity.

Methods. In order to implement effective scientific research used a wide range of research methods was used, namely: analysis and synthesis, scientific studies, systematization and generalization, polls, surveys and statistical processing of results.

Results and discussion. At the beginning of our work, we often heard the question: "And what is it, really, economic thinking?" - and we replied: "And when you choose what to buy in the store, what kind of thinking does it work?" It is not very polite to answer the question to the question, but, consider, why a very talented, for example, a musician rarely becomes wealthy without an impresario; and Sherlock Holmes did not make big money with music, although he was very talented with a violin?

At first, it will probably come to mind that this can be explained by motives and incentives of the activity. And if it is simpler with the incentive for economic activity, because it is always connected with the welfare and financial income, then it is more difficult for motives because they are a personal interest. So, firstly, Holmes was more interested in looking for thieves than performing concerts; and secondly, on what can we earn more, and more regularly?! We have to think, not to be mistaken. Paul Heine (1997, p.15) in his book, "The Economic Way of Thinking," noted that "if a person tried to think economically, he would never stop at the previous level, but would try to achieve more, and, consequently, develop himself".

His opinion is confirmed by the numerous results of the experiments of cognitivists, who argue that all cognitive processes are trained in order to stimulate their activity. And thinking is no exception. What do we mean by the term "economic thinking" as a kind of practical one in terms of opportunity to influence it in the process of economic education? From the point of neurophysiology, thinking, in general, is defined as a process of constant interaction between nerve cells (neurons), in the result of which patterns (style, template) are formed in the synoptic space of brain. The Russian scientist P. Anokhin concluded that: each of ten billion neurons calculated in the human brain, is capable of forming the relations, the number of which is equal to one with the 28 zeros. If you try to write it, you get a number one and 10.5 million kilometers zeros ... From this reasons we do not accept any pessimistic statements about the limited capacity of the human brain. They are limitless!" (Byuzen, 2003, p.30). This allows us to be optimistic about our own research.
In terms of psychology, thinking is a mental process of mediated and generalized reflection (in the human brain) of subjects of subjective reality in their substantial properties, relations and attitudes, and, as a result of which intelligence of personality is formed (Wikipedia, 2018). The process of thinking can be done in two ways: either as a combination of a certain number of images, or as "inner speech", which is like a conversation with yourself, when words are not spoken aloud (Halpern, 2000, p. 31). In our opinion, it will be fair that such a specificity of thinking will spread on the economic one, realized by the person in his professional economic activity, as well as in the process of the transfer of economic knowledge. And to ensure the success of the latest one in educational space, it is necessary to develop, form and promote specific skills and characteristics (or features) of economic thinking of the future specialist. Today we are trying to affect the development of such characteristics of the economic thinking of students:

$\checkmark$ analyticity and scientific substantiation provide the deep analysis, accurate generalizations and conclusions, critical evaluation and effective solution; gives people the vision of the complex world of social production, etc.; enables them to understand the laws of development and functioning mechanisms, basic relations and dependence of the economy;

$\checkmark$ consistency-provides a complex approach to solving economic problems;

$\checkmark$ constructiveness - is directed at solving the economic tasks and ensures high and real results of economic activity;

$\checkmark$ prognostication-the ability to solve economic situations widely, it provides an opportunity to predict the consequences of the decisions taken in various spheres;

$\checkmark$ balance - the skill to apply the theoretical principles into practice effectively and efficiently, evaluate the different economic situation properly and make necessary fully-informed decisions;

$\checkmark$ efficiency -is the ability to solve problems that arise vigorously and effectively, the ability to organize a certain matter, aspirations to perform own responsibilities faithfully, to prove the taken decisions to the full implementation;

$\checkmark$ creativity - the ability to generate non-standard ideas, take into account unexpected circumstances, new phenomena and processes, determined with dynamics of the economy, scientific technological process, the mobility of the structure of production and the needs of society;

$\checkmark$ innovation - the ability to embody new original solutions into practice of professional activity.

It would be also useful to pay attention to such intellectual properties as: independence, depth, flexibility, speed and curiosity. 
Next, it is necessary to determine the methodological tools by which we can influence the development of the indicated characteristics, as well as to find out the direction where there is need for their perfection.

Using the results of R. Sperry about the specific capabilities of the hemispheres of brain, as well as the study of T. and B. Byuzen (2003, p. 33-34, 53), D. Halpern (2000, p. 35) about the modality of thinking, we study the dominance of the hemispheres (on the basis of the Elvin questionnaire) of students of the I-III years of economics and management faculties, as well as the marketing faculty of the state HEI "Kyiv National Economic University named after Vadym Hetman" during 2004-2018. The dynamics of the indicators of modality of thinking of students of the first year remains unchanged and does not depend on the direction of preparation. And most of them (from 50 to $60 \%$ of general number of respondents) are prone to logical way of thinking, that is they have a dominant left hemisphere of the brain. We could not but expect such results, because the whole system of Ukrainian education is aimed at the development of logics, language, operations with numbers, that is, on the mental capacities of the left hemisphere (Byuzen, 2003, p. 32), and the disciplines that develop the imagination, the perception of color, rhythm, gestalt, are considered secondary.

More significant fluctuations of indicators were observed in 2017-2018 academic year when diagnosing was conducted by third-year students of the Faculty of Personnel Management, Psychology and Sociology, field of study "Professional Education (Economics)", who receive dual education for the first time in the history of the activity of the department and the university. They had the opportunity to hear a great number of disciplines of psychological and pedagogical direction compared to other directions of training, to work with the creative team of the Department of Pedagogy and Psychology more time, the teachers of which concentrate on the development of creative abilities of students, and have passed training of development of economic thinking, which is the selective component of their training, under the supervision of the paper author. If the number of students with logical type of thinking did not differ from other specialties practically ( $52.4 \%$ vs. $56.9 \%$ of the number), there were fewer students with dominant creative thinking (19.0\% vs. $31.4 \%)$ and much morewith equal opportunities for using logical and creative thinking ( $28.6 \%$ vs. $11.7 \%$ ).

In our opinion, for a professional (in the field of economics and economic education) to have productive economic thinking, an effective intelligence and formed professional competence, he must have two lines of thinking, and, therefore, we need to develop a balanced, multi-directional productive economic thinking. With this aim, in the framework of educational discipline "Methods of teaching economic disciplines" and "training of economic thinking" (based on the results of research of modality of thinking of students, who get the qualification of teachers of professional training / expert in economics), selected and tested (during the educational process) technologies and techniques for the development of thinking are offered for the increase of productivity of thinking in particular:

$\checkmark$ in order to stimulate the development of a logical type - "a water logics", according to E. de Bono, techniques developed on the basis of the theory of solving the inventive tasks of Henry Altshuler (TRIZ); the elements of techniques by E. de Bono regarding the improvement of the productivity of the brain work with actual data, various kinds of objective information, for example, "six thinking hats" - in the section of methods of thinking "in white, black and yellow hats", or "6 pairs of shoes of image of action" - in the section about "Thinking and actions in gray sneakers or brown shoes";

$\checkmark$ to stimulate creative thinking-methods of nonstandard and creative thinking by Edward de Bono, (eg. effective search of alternatives in the decisionmaking process, "lateral thinking"), techniques of creativity thinking development (eg. M. Mikalko and some others);

$\checkmark$ to stimulate the development of the balanced modality, techniques are offered to all the students, because to mastery them, the use of mental abilities of both hemispheres of brain is a necessary prerequisite: methodology of critical thinking by D. Halpern and techniques for the development of critical thinking of other authors, methodology of development of radiant thinking and the creation of intelligence charts by T. and B. Byuzen, the techniques of "six hats of thinking" and "six pairs of shoes of the way of action" by E. de Bono and some others.

As you know, it is better to master the material that you are teaching yourself, and that's why during the training, students are offered to learn the technique of thinking by one of these techniques to adapt them to the problems of the study of economics and development of economic thinking based on specific economic issues and situations during conducting elements of training sessions or writing course projects, as well as realizing the developed training sessions while undergoing pedagogical practice in the process of teaching economic disciplines. We offer to assess the effectiveness of teaching methods by the method of "TRIZ" - Pedagogy by A. Gin and the analysis of conducted lessons -by methodology "Plus-Minus- 
Interesting" E. de Bono, and, the evaluation occurs via both teachers and students. Effectiveness of author's approach in defining methodologies, their combinations and impact on the productivity of economic thinking are confirmed by the results of change of the modality of thinking of students and the increase of efficiency of intelligence as the ability to use the mind to answer the question creatively and solve practical problems (Pelehrino, 2003, p. 5) of economic and pedagogical nature. In general, during 2017/2018 academic year there was a growth rate of balanced modality of thinking of students by almost $17 \%$, mainly, by reducing the number of students with the dominant creative thinking $(-12.4 \%)$, and insignificant decrease in the number of students with dominant logical thinking (-4.5\%).

Conclusions. In the modern world, it does not matter whether the future profession is related to the economic sphere, because we all need to make economic decisions constantly, engage, in a certain sense, in commerce, "selling" our professional competencies to the manager, obtaining banking services, choosing goods and services, etc., forecasting the consequences of the decisions taken and their impact on financial income and own welfare. According to the Ministry of Education and Science of Ukraine, in 2018, 292 higher educational establishments took in students on the economic specialty, that's $62.4 \%$ of all institutions of higher education in Ukraine (MES Ukraine, 2018). Therefore, in conditions of such a high-level of competition, universities must seek new approaches to training specialists in economics. Competiveness of graduates of KNEU named after V. Hetman, except for the quality of providing educational services, which is confirmed by the university's ratings, can ensure the diversification of educational and professional programs. For example, an expert, who got a Bachelor by the educational professional program "Economic and Business Education", can carry out professional activities in two areas (KNEU, 2018):
- pedagogical - teaching of economics, training, coaching, social and educational activity, organizational, methodological and advisory work, project and public activity in the field of education;

- economic - administration, management, personnel training, consulting in business, sales of educational services, logistics, business, design and social activities in the business.

The presence of duality in training future professionals will encourage the development of specific interdisciplinary traits of economic thought, thus, promoting increase of it as efficiency and productivity. Under the productivity of economic thinking, we understand the number of ideas and decisions that a person has developed in relation to the subject or field of research. The result of productive economic thinking will be alternatives in economic thinking in solving these given problems. And under the effectiveness of economic thinking, we understand the share of ideas and solutions that brought of material or non-material benefits to the personality. The result of effective economic thinking is a balanced decision, with the adoption of which the received benefit will get over the efforts and resources greatly that were spent on its development and implementation into practice. Horizontal or lateral (creative) thinking will contribute to the performance of thinking, and vertical or logical thinking - to efficiency. Radiant (associative) thinking will help to explore solutions fully, that is, it will give the opportunity to develop a professional intelligence and create competence of the teacher of professional training / specialist in economics. At the same time, one can not forget about the implementation of the relevant disciplines in the curriculum and the introduction of techniques and technologies for the development of thinking in the process of economic education. For this purpose, the teachers should possess the following methods and imagine clearly what qualities and how to develop them and cultivate the educational space.

\section{List of references}

Бьюзен, Т. и Бьюзен, Б., 2003. Супермыииление. Перевод с английского Е. А. Самсонова. М.: ООО "Попурри". (Серия "Живите с умом").

Пеллегрино, Р. и Политис, М., 2003. Как повысить свой интеллект? Перевод с английского Н. Ю. Чехонадской. М.: ООО "Издательство АСТ": ООО "Издательство Астрель". (Серия "Шаг за шагом").

Халперн, Д., 2000. Психология критического мышиления. СПб.: Издательство "Питер", 2000. (Серия "Мастера психологии").

Хейне, П., 1997. Экономический образ мышления. Перевод с английского. М.: Изд-во "Каталаксия".

Forbes, 2016. Як стати мільйонером: ТОП-16 найперспективніших сфер роботи. [online] (Останнє оновлення 15 Серпень 2016) Доступно: <http://forbes.ru> [Дата звернення 15 Листопад 2018].

Київський національний економічний університет імені Вадима Гетьмана, 2018. Кафедра педагогіки та психологiï. [online] (Останнє оновлення 16 Жовтень 2018) Доступно: $<$ http://kneu.edu.ua $>$ [Дата звернення 18 Листопад 2018]. 
Міністерство освіти та науки України, 2018. Реєстр суб'єктів освітньої діяльності. [online] (Останнє оновлення 18 серпня 2018) Доступно: <http://osvita.ua> [Дата звернення 19 Листопад 2018].

Вікіпедія. Вільна енциклопедія, 2018. Мислення. [online] (Останнє оновлення 18 серпня 2018) Доступно: <http:/ /uk.wikipedia.org> [Дата звернення 3 Жовтень 2018].

\title{
Translated \& Transliterated
}

Byuzen, T. i Byuzen, B., 2003. Supermyishlenie [Supersoul]. Perevod s angliyskogo EA Samsonova. M.: OOO Popurri. (Seriya "Zhivite s umom"), [in Russian].

Pellegri no, R. i Politis, M., 2003. Kak povyisit svoy intellekt? [How to improve your intelligence?]. Perevod s angliyskogo N. Yu. Chehonadskoy M.: OOO Izdatelstvo AST: OOO Izdatelstvo Astrel. (Seriya "Shag za shagom"), [in Russian].

Halpern, D., 2000. Psihologiya kriticheskogo myishleniya [Psychology of critical thinking]. SPb: Izdatelstvo "Piter", 2000. (Seriya "Master of Psychology"), [in Russian].

Heyne, P., 1997. Ekonomicheskiy obraz myishleniya [An Economic Way of Thinking]. Family tree s angliyskogo. M.: Izd-vo "Katalaksiya", [in Russian].

Forbes, 2016. Yak staty milionerom: TOP-16 naiperspektyvnishykh sfer roboty [How to become a millionaire: TOP16 of the most promising spheres of work]. [online] (Ostannie onovlennia 15 Serpen 2016) Dostupno: $<$ http://forbes.ru $>$ [Date zvernennia 15 Lystopad 2018], [in Ukrainian].

Kyivskyi natsionalnyi ekonomichnyi universytet imeni Vadyma Hetmana [Kyiv National Economic University named after Vadym Hetman], 2018. Kafedra pedahohiky ta psykholohii [Department of Pedagogy and Psychology. [online] (Ostannie onovlennia 16 Zhovten 2018) Dostupno: <http://kneu.edu.ua> [Date zvernennia 18 Lystopad 2018], [in Ukrainain].

Ministerstvo osvity ta nauky Ukrainy, 2018. Reiestr subiektiv osvitnoi diialnosti [Registry of subjects of educational activities]. [online] (Ostannie onovlennia 18 serpnia 2018) Dostupno: <http://osvita.ua> [Date zvernennia 19 Lystopad 2018], [in Ukrainian].

Wikipedia. Vilna entsyklopediia [Wikipedia Free Encyclopedia], 2018. Myslennia [Thinking]. [online] (Ostannie onovlennia 18 serpnia 2018) Dostupno: <http://uk.wikipedia.org> [Date zvernennia 3 Zhovten 2018], [in Ukrainian].

\section{Продуктивне економічне мислення - основа формування фахових компетентностей студентів спеціальності "Професійна освіта (Економіка)"}

\author{
Олена Булавіна,
}

кандидат економічних наук, доцент, доцент кафедри педагогіки та психології ДВНЗ "Київський національний економічний університет імені Вадима Гетьмана"

Реферат. Стаття присвячена методичним аспектам розвитку економічного мислення майбутніх педагогів професійного навчання та фахівців з економіки, оскільки його продуктивність забезпечує успішність формування професійних компетентностей студентів, які отримують освіту за освітньо-професійною програмою "Професійна освіта (Економіка)" у ДВНЗ "Київський національний економічний університет імені Вадима Гетьмана". Компетентнісний підхід - тренд сучасного освітнього простору, і процес мислення особистості $€$ центром проблеми розвитку особистості та формування іiї як особистісних, так і професійних компетентностей, що, в свою чергу, завдяки унікальності, неповторності та синергетичності буде забезпечувати конкурентні переваги майбутнього фахівця на ринку праці. Метою статті є: проаналізувати специфіку економічного мислення студентів, які отримують вищу економічну освіту за програмою "Професійна освіта (Економіка)"; сформулювати основні характеристики (риси) економічного мислення, які необхідно розвивати в процесі економічного навчання; довести необхідність та обгрунтувати методичні підходи до розвитку продуктивного економічного мислення студентів, що забезпечить формування фахових компетентностей з метою стимулювання ефективності професійної діяльності. Задля здійснення результативного наукового пошуку було використано широкий спектр методів дослідження, а саме: аналіз та синтез, наукове обгрунтування, систематизація й узагальнення, опитування, анкетування і статистична обробка результатів.

У ході дослідження були отримані наступні висновки та результати. Автором розкривається специфіка економічного мислення, його основні риси та прояви у професійній діяльності. Економічне мислення розглядається як різновид практичного мислення суб'єкта професійної діяльності. Це, в першу чергу, процес, а, отже, його можна розвивати та вдосконалювати. Дослідники природи нейронів (нейрофізіологи) констатували той факт, що можливості людського мозку безмежні. У такому ракурсі потрібно вирішувати завдання методичного характеру: яким чином, за допомогою яких інструментів можна в цілому розвивати економічне мислення та в процесі економічного навчання формувати конкретні його характеристики: аналітичність, критичність, системність, конструктивність, прогностичність, зваженість, діловитість, креативність та інноваційність. Досліджуючи ці аспекти, автором обгрун- 
товано та систематизовано досвід застосування технік і прийомів розвитку мислення особистості в освітньому процесі (на прикладі навчальних дисципліни "Методика викладання економічних дисциплін" і "Тренінг розвитку економічного мислення", яким притаманний міжпредметний характер), з урахуванням первинної модальності мислення студентів; окремо виділені техніки та прийоми стимулювання розвитку логічного (лівопівкульного), творчого (правопівкульного) та збалансованого мислення в процесі навчання; оцінено їх вплив на модальність та зміни у типах мислення студентів, що доводить необхідність імплементації конкретних методик розвитку економічного мислення у процес підготовки фахівців бакалаврського рівня за спеціалізацією "Економічна та бізнес-освіта" 3 метою стимулювання продуктивності та результативності мислення. Під продуктивністю економічного мислення ми розуміємо кількість ідей та рішень, що їх виробила особистість стосовно предмета або сфери дослідження. Результатом продуктивного економічного мислення будуть альтернативи у вирішенні поставлених завдань / проблем. А під ефективністю економічного мислення ми розуміємо частку ідей та рішень, що принесли особистості матеріальну чи нематеріальну користь. Результатом ефективного економічного мислення є зважене рішення, у підсумку прийняття якого отримана користь значно переважить зусилля та ресурси, затрачені на його розробку та впровадження у практику. Забезпеченню продуктивності мислення буде сприяти горизонтальне або латеральне (творче) мислення, а ефективності - вертикальне або логічне мислення. Радіантне (асоціативне) мислення допоможе всебічно дослідити рішення, що, в підсумку, дасть змогу розвинути професійний інтелект та на його основі сформувати компетентність педагога професійного навчання / фахівця з економіки.

Ключові слова: економічне мислення, продуктивне економічне мислення, модальність мислення, професійна компетентність, техніки та прийоми розвитку мислення.

Received: 12 May 2019

Accepted: 24 May 2019 